\title{
THE ATTITUDES OF FRIENDLY SOCIETIES TOWARDS THE MOVEMENT IN GREAT BRITAIN FOR STATE PENSIONS, 1878-1908*
}

The last three decades of the nineteenth century were marked in British social history by a vigorous and far-reaching debate about the causes and incidence of poverty amongst the elderly. By the early 1890 s this controversy had produced a sharp cleavage of opinion between those commentators who held that old-age pauperism was largely a product of character defects and those who attributed it to certain social and economic ills which the individual, acting alone, could never hope to remedy. Social thinkers who subscribed to this latter view - the loosely labelled collectivist school of thought - were not content, however, merely with the work of analysis; they were equally anxious to find a panacea for one of the main social problems of the day. In the end the solution they most widely canvassed was the introduction of an old age pensions scheme in which the state would have a vital rôle to play. But perhaps of more significance for the development of social services in Great Britain, three of the leading advocates of state intervention endeavoured, in their own distinctive styles, to translate this general declaration of intent into detailed programmes of action.

The first of these proposals was formulated by Canon W. L. Blackley in 1878. Arguing that the labourer could only be expected to save "at a certain period of his life, namely, while he is still young and unencumbered," he came out decisively in favour of a compulsory, nation-wide system of insurance for the adult male population of the country. The wage-earner, according to Blackley, should be obliged, between the ages of seventeen and twenty-one, to put aside a total of $£ 14$ with the central government. Once this contractual obligation had

* This article is a slightly extended version of a paper read at a meeting of Scottish Economic Historians at the University of Edinburgh, December 1969. I wish to thank Professor Asa Briggs of the University of Sussex, Professor S. G. E. Lythe and Dr J. Butt of the University of Strathclyde, Dr R. G. Wilson of the University of East Anglia, and the editorial board of this periodical, for their helpful criticisms of an earlier draft of this paper. I am also indebted to Dr Wilson for several references. 
been fulfilled, he automatically became eligible for a sickness payment of $8 /-$ per week until he attained the age of seventy. Thereafter he was to qualify for a weekly pension of $4 /-.^{1}$

Almost thirteen years were to elapse before another attempt was made to produce a coherent pensions plan for the consideration of the electorate. Then in 1891, separated by only a few months, Joseph Chamberlain and Charles Booth presented to the public their widely divergent blueprints for alleviating the plight of the elderly outside the forbidding framework of the $\mathbf{1 8 3 4}$ New Poor Law.

Chamberlain cautiously advanced the idea of a permissive contributory scheme under the terms of which the individual's own efforts to insure for his old age were to be given tangible encouragement in the form of a cash supplement from the resources of the Exchequer. During 1892 this commitment to the concept of social welfare was to be embodied in a series of pensions proposals. ${ }^{2}$ Among other things a category of "Class III" policy-holders was to be created "in order", as Chamberlain put it, "to ensure the co-operation of the friendly societies". All who wished to be included in this grouping were required to insure for a pension of $£ 6: 10:-$ per annum either through the Post Office Savings Bank or through a friendly society. Their reward for showing such foresight was to have their pension doubled by a direct donation from the Treasury. However, a state subsidy of this nature could not be given unconditionally. Two specific conditions remained to be fulfilled. Firstly, in order to protect the insurer from the consequences of a friendly society's failure, it would be necessary to separate a thrift agency's superannuation fund from its income derived from contributions for other purposes. Secondly, "there would be no harm in requiring that the scale of contributions should be controlled by some State authority, and it might further possibly be a matter of arrangement between the friendly societies and the State that the funds of this particular branch should be deposited with the State in return for which the State might give a little higher interest than it now does." 3

1 W. L. Blackley, "National Insurance: A Cheap, Practical and Popular Means of Abolishing Poor Rates", in : Nineteenth Century, Vol. IV (1878), pp. 840, 851-3. The size of the financial contribution to this scheme was later revised. In 1884 Blackley argued that a sum of $£ 10$ would be sufficient to provide a sickness benefit of $8 /$ - per week and a pension of $4 /-$ after the individual had reached the age of seventy. See W. L. Blackley, Thrift and Independence (1884), pp. 171, 175. 2 The main outline of Chamberlain's "Class III" pensions proposal was presented to the electorate of Birmingham in July 1892. See Foresters' Miscellany, August 1892, p. 142, quoting from Birmingham Daily Gazette, 15 July 1892. 3 Royal Commission of the Aged Poor, Vol. III, Minutes of Evidence [Parliamentary Papers, 1895, C. 7684-II, XV], qq. 12225, 12230. 
Both Blackley and Chamberlain had thus in their different ways linked pensions with the insurance principle. Charles Booth on the other hand was at once more drastic and more simple in evolving his own solution to the same question. In his original paper to the Royal Statistical Society in 1891 Booth had examined in some detail the interrelated problems of pauperism and old age. After sifting the available evidence he had concluded that "nearly eight-ninths of that [pauperism] from 65 and upwards must be accounted old age pauperism, and of the remaining one ninth not less than half will have fallen into pauperism through such causes of misfortune as sickness or incapacity."1 The essence of his thesis was that debility associated with advancing years had compelled most of these men and women to seek succour from their local Boards of Guardians. People who had once been hard-working citizens but whose wages had been insufficient to enable them to save for their old age, comprised the majority of aged paupers. ${ }^{2}$ Booth felt deeply that it was wrong to stigmatise, as the Poor Law did, those who were thus situated. One purpose, therefore, of his pensions scheme was to remove, as far as possible, that stigma, by securing the introduction of a non-contributory state pension of $5 /$ - per week. All who were over 65 years of age were to be eligible for this grant without having to undergo any form of character or means test.

Inevitably these three pensions plans provoked a ferment of debate amongst the socially conscious and politically articulate sections of Victorian society. By the late 1890 s politicians of both the leading parties were being compelled to examine anew the idea that the State had little or no rôle to play in the realm of social welfare outside the Poor Law. Trade unionists at roughly this same period in time were also becoming increasingly critical of Gladstonian notions of "retrenchment and reform". The sequel to their widespread questioning of the "received values" of nineteenth century political economists was the establishment in 1899 of the National Committee of Organised Labour to agitate for universal, non-contributory pensions along the lines of Booth's initial proposal. ${ }^{3}$ Last but not least the numerically powerful and socially influential friendly societies' movement, drawing its four and a quarter million members from the ranks of the lower middle-

1 Journal of the Royal Statistical Society, Vol. LIV (1891), p. 631.

2 Royal Commission on the Aged Poor, Vol. III, Minutes of Evidence [PP, 1895, C. 7684-II, XV], q. 10359. Booth argued that two-thirds of the class who had received low wages during their life-time resorted to the Poor Law at some time during their old-age. "This I consider too large a proportion of any class to make a sweeping condemnation of."

1st Annual Report of Organised Labour for Promoting Old Age Pensions for All, 1899-1900 [n.d.]. 
classes and the better-paid elements of the working-classes, was forced during the 1890 s and 1900 s to define its own attitude towards the increasingly vocal demands for state pensions. It is largely with the reaction to this agitation of the two great Affiliated Orders, the Manchester Unity of Odd Fellows and the Ancient Order of Foresters, that the remainder of this paper is concerned. ${ }^{1}$

The intervention of the friendly societies in the pensions controversy was prompted by essentially mundane motives. Their basic pre-occupation had always been to safeguard their own well-being. Hence any type of action, either by the state or by other voluntary associations, which might encroach on their independence and/or restrict their future development had to be resisted. Until 1902 state pensions were viewed precisely in this light by the National Conference of Friendly Societies. This posture helps the social historian to understand why thrift agencies were more afraid of the schemes of Blackley and Joseph Chamberlain than the ideas of Booth. Booth's plan, it was argued, might affect their prosperity in an indirect manner by weakening the incentive among the working-classes to make private provision for their declining years. Blackley's and Chamberlain's schemes, however, were specifically insurance proposals which, it was felt, could mark the beginning of the end of the friendly societies' existence. The widespread fear among the Affiliated Orders was that if Blackley's comprehensive plan were implemented, it would make private thrift institutions irrelevant to the needs of the nation. Similarly Chamberlain's "Class III" proposal, if persevered with, would be but the prelude to some form of nationalisation of the societies' assets, since it would involve from the outset a considerable measure of state control over their finances. It is therefore scarcely surprising to discover that when, in

1 Professor B. B. Gilbert has graphically described the social structure of the friendly societies in the closing years of the nineteenth century. Although almost half of the adult male population of Britain were friendly society members in 1891, the movement "made no appeal whatever to the grey, faceless, lower third of the working class. Friendly society membership was the badge of the skilled worker." B. B. Gilbert, The Evolution of National Insurance in Great Britain (London, 1966), pp. 166-7. In the early 1890s the Ancient Order of Foresters had 830,720 members and the Manchester Unity of Odd Fellows 769,503 . "The total numbers of all the branches of affiliated orders registered as such, and making returns [to the Chief Registrar of Friendly Societies], was 1,727,809." See Royal Commission on the Aged Poor, Vol. III, Minutes of Evidence [PP, 1895, C. 7684-II, XV], q. 11033. In other words, over one third of the total membership of the friendly societies' movement was claimed by the two great Affiliated Orders. 
the early years of the twentieth century, the friendly societies of Great Britain, meeting in National Conference, did at last come round to the view that state pensions were not necessarily inimical to their own well-being, the scheme which they adopted was much nearer to that of Booth than the contributory plans of Blackley and Chamberlain. It is against the backcloth of these value-judgments that much of the thinking of the Affiliated Orders on the pensions question has to be set.

Given these general assumptions, the friendly societies' attack on Blackley's proposal could hardly be interpreted by its author as an unexpected development. According to the Societies, the scheme possessed two major defects. Firstly, it was to be both universal and compulsory. There existed no loophole which would enable the individual to contract out of the state-run system. Secondly, it included in its scope sickness as well as superannuation benefits. ${ }^{1}$ It would thus destroy the virtual monopoly which the voluntary agencies had hitherto enjoyed in the sickness field. Alarmed by these implications the friendly societies assumed an attitude of unrelenting hostility to the plan.

At the very outset of their campaign they were not afraid to admit that they were defending their own interests. If, they asserted, Parliament were to accept Blackley's ideas, it would be deliberately undermining their own prosperity; for compulsory state insurance could only succeed in depriving them of much of their business. These views were perhaps most forcibly put forward by Thomas Walton, Grand Master of the Manchester Unity of Old Fellows, when he addressed his society's Annual Movable Committee in 1883.

"The result", he asserted, "[of Blackley's scheme] would be in the first place to cripple and ultimately destroy existing voluntary organisations, as it is only natural to suppose that if a persen is compelled to join one Society, and that Society guaranteed by the State, he will not join another as a voluntary act." 2

Another critic echoed these sentiments. National insurance, in the eyes of the Rev. J. Frome Wilkinson, meant that friendly societies would be superseded by "an autocratic form of State-Socialism, which

1 Blackley later offered to drop that part of his scheme which dealt with the problem of sickness. Such a gesture however had no impact upon the friendly societies' implacable hostility to the whole of Blackley's plan. See B. B. Gilbert, op. cit., pp. 163-4.

2 The Quarterly Magazine of the Independent Order of Odd Fellows July 1883, p. 181. 
would sink and merge the man in the state, and place the prudent and imprudent, the thrifty and thriftless on the same platform". ${ }^{1}$

Yet such an outcome would inflict real injury on the working-classes. Everyone would become "a nursling of the State", although it was not "by nursing that our country stands so high amongst the nations of the world, neither is it by State nursing that the Friendly Societies of this country occupy so eminent a position." 2 A system of state insurance would sap the moral fibre of the nation and render "the people unfit for the wise use of the liberty that is left to them". ${ }^{3}$ Above all it would penalise those "intelligent working men" who strove to practise the "economic virtues". Thus if the scheme were adopted, the nation as a whole - and not merely the friendly societies - would be the loser. The societies were therefore arguing that the well-being of the state coincided with the preservation of their own integrity. Given this premise, it followed that when a specially concened national conference of friendly societies condemned in 1887 Blackley's plan as "being detrimental" to their own development, ${ }^{4}$ they at the same time believed that they were thereby safeguarding the social health of the British people.

Much of this attack, however, rested on very uncertain foundations. Walton's belief for instance that there would be a massive falling-off in the membership of friendly societies if Blackley's scheme were endorsed by Parliament, was almost based on a "wage-fund" analysis of working-class thrift. He was implying that the amount of money available for all forms of working-class saving was unalterably fixed and therefore that contributions to a state superannuation plan could only be made at the expense of the prosperity of friendly societies. Yet this line of reasoning took no account of two important considerations. In the first place the fundamental factor governing the flow of funds to thrift agencies was the prevailing economic climate. It was, for example, beyond dispute that the main determinant in the growth of friendly societies in the second half of the nineteenth century had been the upward movement in real wages. This fact was in itself an ample refutation of all 'wage-fund' notions about working-class thrift. It was logical to conclude that the downswing of the trade cycle, rather than

1 Ibid., November 1885, pp. 329-30. Letter from the Rev. J. Frome Wilkinson. While, however, Wilkinson was opposed to pensions based on national insurance contributions, he was later to come out strongly in favour of Booth's plan. See on this point Rev. J. Frome Wilkinson, Pensions and Pauperism (1892).

The Quarterly Magazine of the Independent Order of Odd Fellows, July 1883, p. 181 .

Ibid.

The Odd Fellows' Magazine, July 1887, p. 204. This conference was convened by the Foresters and the Manchester Unity. Eighteen friendly societies were represented, with a total membership of 1,928,427. Ibid., pp. 195, 204. 
Blackley's modest proposals, would pose a much more substantial threat to their future prospects. Secondly, Walton and his supporters overlooked - or rather, did not mention - the point that all contributions for state pension and sickness benefits were to be paid by the individual when he was between the ages of seventeen and twenty-one. Thereafter each man would have ample opportunity to supplement his state pension by participating in private superannuation schemes.

The friendly societies were equally guilty of ignoring Blackley's attempt to show that his plan could bring to them a great increase in business. Blackley's primary aim was to abolish the practice of taxing the thrifty, by means of the poor rate, "for the support of a large class of wasteful, thriftless, improvident persons". National insurance could alone achieve this end, since it would enforce "on wasteful men the duty helping themselves without injuring anyone". That section of the working-classes which had hitherto made no contact with "our voluntary organisations", was to be given a compulsory lesson in the virtue of saving. Indirectly therefore national insurance might stimulate the growth of thrift amongst the hitherto improvident elements in society, "and so greatly multiply the membership of good friendly societies and increase their usefulness". But the scheme was also designed to encourage "the really-independent spirited man" to continue his association with the Affiliated Orders and their like. State benefits, according to Blackley, would only suffice to keep a man from falling into pauperism. They would accomplish nothing more. Hence there was still an incentive for the individual to make private arrangements for additional comforts in his old age through existing thrift agencies. ${ }^{1}$ Blackley in essence was arguing that no matter from what angle his proposals were examined their net effect would be beneficial, not harmful, to the friendly societies' world.

This case was never answered except in emotional terms; and yet this in the end was sufficient to guarantee its defeat. ${ }^{2}$ Few friendly society members were prepared to dissent from the lead which their officials had given them; and without their conversion nothing substantial could be achieved. As Blackley's widow was to observe some twenty years later, "no movement in favour of a National Insurance

1 This paragraph is based on Blackley's "The Effect of National Insurance on Sound Friendly Societies", in: The Quarterly Magazine of the Independent Order of Odd Fellows, July 1881, pp. 182-5.

2 The select committee of the House of Commons which was appointed to examine Blackley's scheme, presented its conclusions to Parliament in 1887. In Gilbert's words, "it was unable to agree that the scheme was actuarially sound and declared itself 'disposed to wait on the future development of public opinion'." B. B. Gilbert, op. cit., p. 163. For friendly society reaction to this report, see The Odd Fellows' Magazine, September 1887, pp. 253-61. 
could possibly be carried out against the determined opposition of bodies numbered in the millions and highly organised like the Friendly Societies."1

\section{III}

When Chamberlain took up the pensions question in 1891-2, he was anxious to avoid repeating what he regarded as Blackley's cardinal error. To his mind it was essential to conciliate and consult the friendly societies at every stage of the proceedings since "their approval and if possible active assistance ... is almost a necessary condition of the successful promotion of any scheme of provision for old age pensions." 2 In concrete terms this meant that any contributory pensions plan based on the twin concepts of universality and compulsion had to be discreetly dropped. ${ }^{3}$ Initially a state superannuation scheme could only be organised along voluntary lines and in a manner acceptable to friendly society opinion. It was to this end that Chamberlain had suggested the creation of a category of policy-holder serving specifically the interests of members of thrift agencies. Unfortunately however, for the survival prospects of this proposal, the leading spokesmen of the Affiliated Orders treated any form of state subvention as a lever which might ultimately be used against them. When Chamberlain later linked his "Class III" plan with a thinly-veiled threat of state regulation of friendly society finances, his defeat, always likely, was made certain. Despite his determination to avoid Blackley's fate, he was to find that he too had fallen foul of the Affiliated Orders.

There had in fact been ominous indications of friendly society reaction to Chamberlain's manoeuvres before ever the "Class III" proposal had been formulated. As early as 1891 the Ancient Order of Foresters had been unhappy about Chamberlain's references to a government subsidy. Although this proposition had only been discussed in the most general

1 M. J. J. Blackley, Thrift and National Insurance as a Security against Pauperism, with a Memoir of the Late Rev. Canon Blackley and a Reprint of his Essays (1906), p. 40, quoted in B. B. Gilbert, "The Decay of Nineteenth Century Provident Institutions and the Coming of Old Age Pensions in Great Britain", in: Economic History Review, 2nd Series, Vol. XVII, No 3, p. 559.

${ }^{2} \mathrm{JC}$ 6/3/4/2 (Joseph Chamberlain Papers, University of Birmingham Library). Extracted from undated letter of Chamberlain to "The Rural Worker". Because of the necessity of cultivating friendly society opinion, Chamberlain concluded that it would be "most inexpedient to include [in a pension scheme] any provision for insurance against sickness or accident".

' Chamberlain, however, was of the opinion that compulsory insurance for old age had much to commend it. He refrained from pressing it simply because the friendly societies would have destroyed such a plan. The Times 19 November 1891. 
terms, its implications seemed clear enough. To Bro. Radley, the High Chief Ranger of the Foresters, the logical corollary of state grants was government interference in the internal affairs of voluntary organisations. Such an event had to be avoided at all costs; for the present generation of members had a sacred duty to discharge to their posterity. That duty consisted in handing on to their children "the best right of Englishmen - the right of independence, of self-government - which should not be bartered away for a mess of pottage which does not exist in reality."' Speaking at the Order's 1891 High Court Meeting he again returned to this theme. "Care must be taken that the rising generation are not enticed by bribes drawn from the pockets of those who esteem their freedom or forced by legislative compulsion to exchange the stimulating atmosphere of independence and work for an enervating system of mechanical obedience to State management and control - the certain sequel to State subsidy."2

Chamberlain was thus given advance warning of the likely reception which would greet any contributory pensions plan that aimed at promoting co-operation between the friendly societies and the state. However, he resolved to persevere with his various schemes because he believed that once their underlying principles were understood, voluntary bodies would see that they conferred direct benefits on them. All that was required of him was to show that the friendly societies' fears of state intervention were largely misplaced. Incipient hostility would then, he hoped, be converted into enthusiastic support for his projects. Chamberlain therefore tried during 1892 to reassure friendly society opinion. A state subsidy, he proclaimed, "does not give us any claim whatever for further control over the Friendly Societies. We leave them standing exactly as they are now. We don't ask for further interference; we don't want it." 3 Even in the short-term, however, it was to prove impossible to reconcile this statement with the two very specific conditions which were to be later attached to the "Class III" proposal. Not surprisingly the two great Affiliated Orders remained unconvinced.

Their feelings were summed up by the Executive Council of the Foresters when it asserted that "in our opinion the policy of complete freedom from any financial association with the State is the only safe policy." A similar conclusion was reached by the pensions sub-com-

'Foresters' Miscellany, August 1891, p. 158.

2 Ibid., September 1891, p. 178.

Ibid., August 1892, p. 142, extracted from the report of Chamberlain's speech in Birmingham Daily Gazette 15 July 1892. At this same meeting he outlined in detail his "Class III" proposal.

"Ibid., February 1893, p. 343. 
mittee of the National Conference of Friendly Societies in its report to the 1893 meeting. ${ }^{1}$ Chamberlain's proposals had to be opposed, since they threatened to subvert the independence of the friendly societies just as effectively as ever Blackley's scheme would have done. By acting in this fashion all voluntary bodies would thus avoid the temptation of making even the smallest contact with the state. If on the other hand that contact were allowed to take place, "a small State intervention" in their affairs would quickly develop into "something bigger". In the words of T. B. Stead, Permanent Secretary of the Ancient Order of Foresters, it was easier "to defend the outwork [of the friendly societies' world now by refusing to have any truck with such schemes as Chamberlain's] than to have to defend the citadel after". ${ }^{2}$

In the end little came of all Chamberlain's efforts to promote an acceptable contributory pensions plan. The only positive response which his proposals had evoked from those voluntary organisations which were to have been the cornerstone of his system, was that of deep and unrelenting hostility. By December 1894 he openly acknowledged the hopelessness of his task. He had originally set out to try to secure the support of the friendly societies for a permissive from of insurance. They had replied by warning "me off [old age pensions] as though I were an intruder on their domain and a poacher on their preserve." In these words a disillusioned man described the failure of a campaign.

\section{IV}

Yet the attitude of the friendly societies towards the elderly was not entirely negative. Their leaders, for instance, were acutely aware of both the reality of working-class indigence and the sufferings and privations which so often accompanied old age. But in their search for a panacea for these social evils, they were initially at any rate prisoners of the prevailing individualist philosophy of the day. Almost invariably in the 1890s their main solution to the problem of old-age pauperism was akin to that of the Charity Organisation Society which regarded

1 Ibid., May 1893, p. 37. The report was described as being "strongly averse to the acceptance of subsidies by Friendly Societies for the purpose of superannuation, either from Imperial or local taxation".

2 Royal Commission on the Aged Poor, Vol. III, Minutes of Evidence [PP, 1895, C. 7684-II, XV], q. 12436. Evidence of T. B. Stead, Permanent Secretary of the Foresters. He was to be succeeded in his office by his son, J. Lister Stead. ' Foresters' Miscellany, February 1895, p. 332. Chamberlain's speech to a gathering of Friendly Societies' members at Birmingham on 7 December 1894. 
any form of state benefit as calculated to corrupt the moral fibre of the British working-man. ${ }^{1}$ This close identification in outlook at this point in time between the COS and the Affiliated Orders was best expressed by a policy statement of the Executive Council of the Foresters on "self-help" and old age. "Self-help", it was confidently asserted, "self-reliance, and self-dependence have been potent factors for the improvement in the condition of the workers in the past; and we are convinced they are the true factors for the problem of help in old age in the future." 2

What was required was a propaganda campaign to persuade "the people of England ... to exercise a greater self-denial in the hour of strength, in order to secure themselves against hardship in the hour of old-age."3 There was thus common agreement in the early 1890s between the COS and the major friendly societies about the goal at which the working-classes should aim. Where they differed was in their discussion of the means by which that end should be secured.

The COS's policy was beautiful only in its simplicity. If the Poor Law were stringently administered, then the able-bodied would be compelled to make provision to meet the ordinary contingencies of life, while the elderly would be deterred from applying for relief unless they were in the direst straits. In the long-term self-help would triumph because the alternative to providence would be so fearsome. Little of this case rested on an analysis of social structure, income patterns, family size, or the devastating effects on living standards of sharp fluctuations in the general level of economic activity. Despite Booth's

1 The Charity Organisation Society, founded in 1869 and a stern upholder of a deterrent system of Poor Law administration, exercised immense influence on society's thinking about general welfare problems during the last third of the nineteenth century. Although it opposed virtually every proposal to extend the scope of the state's involvement in the field of social welfare, it did play an important role in the development of social casework. It tried to ensure that the multitude of private relief-giving agencies did not administer relief in an indiscriminate fashion. Relief, it argued, should only be given after a full and proper analysis of the applicant's background. It was too concerned, however, with trying to identify the operation of the principle of self-help with "character" to continue to exercise its powerful hold on public opinion after the emergence of statistical investigations into poverty and its causes. Booth and Rowntree between them administered a blow to its standing from which it was never to recover. Hereafter the Charity Organisation will be cited as the COS. For its history, see C. L. Mowat, The Charity Organisation Society 1869-1913 (London 1961).

2 Forester's Miscellany, February 1893, p. 343. Extract from policy statement of the Executive Council of the Foresters.

s Ibid., August 1891. Speech of Bro. Radley, High Chief Ranger of the Foresters. 
work on poverty in the metropolis, the Society remained firmly wedded to the belief that pauperism could best be overcome by encouraging the individual to undergo a process of moral regeneration.

The friendly societies however could not afford to ignore in this fashion the inter-relationship between the size of a family's aggregate income and its pattern of expenditure. The Foresters in particular stressed the correlation which existed between low earnings and the amount of pauperism among the aged. In their view much of the poverty to be found amongst the elderly in the 1890s was not the product of character defects. More often than not it was the tragic sequel to belowsubsistence earnings. Many who were so placed, had led lives of diligent toil; but "they have had such a limited income as to be barely able to provide the absolute requirements of food, clothing, and shelter." Yet such people did not need "a State-aided Pensions Fund, drawing its help from the taxes of the land levied upon rich and poor, but the means of obtaining a larger income during working life. Let the workers get a larger share of the profits resulting from their own labours, and we venture to think that generally they may be trusted to make all those provisions which a sense of duty requires of them."1 Self-help, in other words, could only operate effectively after this "levelling-up of social inequalities" had taken place. ${ }^{2}$ But higher wages would not of course help those already too old to work. Society could only discharge its obligations to this section of the deserving poor if there were a complete revision of the spirit which informed the Poor Law. It was here worse than useless to adopt the stringent tests which the COS demanded; for these would be applied to people who stood no chance of being reabsorbed into the labour market and who, throughout their working lives, had been paid inadequate wages. In this context - and in this context only - the Foresters rejected "self-help" as a meaningful or indeed helpful concept. In its stead they made a plea, in the name of common humanity, for a more flexible Poor Law to deal with this problem of "honest old-age poverty". ${ }^{3}$

These policies could not of course be realised overnight. A "national minimum" or "social" wage, for example, would almost certainly involve a fundamental reappraisal and reorientation of the rôle which the government had hitherto occupied in the economic sphere. Al-

1 Ibid., December 1891, p. 271.

2 Ibid., September 1893, p. 179. Extract from the speech of Bro. J. Prembery, the High Chief Ranger, to the Annual Court Meeting of the Foresters. "There is", he proclaimed, "real poverty upon the earth, and every worker ought to have the power in some lawful sphere to reap the fruit of his labour."

3 Ibid., April 1892, p. 4. 
though this fact was nowhere explicitly stated in these terms, it was the logical conclusion of the whole of the Foresters' argument. Market forces had failed to produce an equitable distribution of the "national cake"; hence the mechanism of the market had to be subjected to outside control. Paradoxically enough, in their desire to establish conditions favourable to the operation of the "Smilesian virtues", the Foresters were unwittingly arrogating to the state far more extensive powers than was ever envisaged by either Blackley or Chamberlain.

Nonetheless the gap between these aspirations and what the friendly societies had thus far accomplished in the pensions field destroyed much of the outsider's faith in this vision. Although the two great Affiliated Orders ran their own superannuation schemes, the vast majority of their members had remained aloof from them. The Foresters' first pension plan had ended in complete failure. During its ten years' life-span - from 1883 to 1892 - it had attracted precisely three subscribers out of the Order's total membership of eight hundred thousand. ${ }^{1}$ The Manchester Unity of Odd Fellows' initial scheme could boast of a considerable improvement on these figures; but even its five hundred contributors - the total attained by 1893 - represented very much less than one per cent. of its members. ${ }^{2}$ The blame for these abysmal results had to be laid very firmly at the door of the Affiliated Orders themselves. For years their sickness funds had been incurring a liability which, in actuarial terms, they had not been designed to meet. In the words of J. Lister Stead, the Foresters' Permanent Secretary, friendly societies were "paying as sick pay to members what are virtually pensions for which members have not paid". ${ }^{3}$ There was thus little incentive for the individual to participate in a separate superannuation scheme when his existing sickness contributions were in effect serving this end.

Inevitably this policy accentuated the serious financial difficulties which most of the major societies were experiencing during the course of the 1890s.4 Within the ranks of the Foresters, for example, some

1 Royal Commission on the Aged Poor, Vol. III, Minutes of Evidence, [PP 1895, C. 7684-II, XV], qq. 12425-6.

2 Ibid., q. 11373. Evidence of Reuben Watson, Actuary to the Manchester Unity of Odd Fellows.

Foresters' Miscellany, March 1894, p. 379.

4 The root causes of the financial troubles of the major friendly societies in this period have been analysed by Professor B. B. Gilbert. Among other things they failed to understand the precise relationship between longevity and the pattern of sickness claims. Reform of their finances was also inhibited by the keen competition which existed for new members, the failure of their officials to impress on the rank-and-file the meaning of "actuarial soundness", the payment of what was essentially a pension to their elderly members out of their sickness 
Courts of the Order had collapsed "under the pressure of claims made for sickness which were in fact due to the infirmities of old age". ${ }^{1}$ But while the leaders of friendly societies deplored this state of affairs, they did singularly little to remedy it. Apart from an inbred sense of loyalty to their elderly membership, fear that a unilateral reorganisation of their subscription rates and their financial arrangements would lead to a heavy loss of members deterred the executives of most friendly societies from making the necessary reforms in this field.

The Foresters were the most active of the Affiliated Orders in trying to focus the attention of their membership on this particular problem, although their proposals to remove this source of weakness contained many unsatisfactory features. Despairing of ever getting their existing members to endorse a compulsory pensions plan which would apply to themselves and of thereby easing the fearsome burden which their sickness funds were called upon to bear, successive Foresters' Executive Councils confined their attention to future recruits. At several High Court meetings the question of compelling all new entrants to subscribe to the society's superannuation scheme was broached, although even this essentially limited approach met with little success. In 1892 the High Chief Ranger, Bro. Crickmer, withdrew the proposal without submitting it to the vote, because "I don't believe more than a dozen hands would have been held up for it." 2 In 1893 scarcely fifty out of the four hundred delegates were in favour of the plan, while in 1894 the debate on this topic was terminated after a closure motion had been passed. ${ }^{3}$ When a similar proposal was presented to the National Conference of Friendly Societies it fared scarcely any better. The 1894 gathering refused to give its blessing to the project, while some four years later the National Conference adopted a resolution which, by asserting that responsibility for compulsory pensions schemes lay with the individual

funds, and the upward movement of interest rates during the Boer War. See B. B. Gilbert, op. cit., pp. 171-180, and loc. cit., pp. 553-58.

1 Foresters' Miscellany, July 1894, p. 99.

Ibid., October 1892, p. 230.

Ibid., September 1893, p. 171 and September 1894, pp. 192-3. The Foresters in fact tried to persuade the Manchester Unity in February 1892 to agree to a concerted approach to this problem. The reply of the Manchester Unity was summarised in their Directors' 1892 Report. The Foresters had approached them "with the object, if possible, of finding a common ground of action in compelling future entrants to subscribe for superannuation. The Directors expressed the opinion that the principle contained in the suggestion cannot be carried out unless either collective action is taken by the whole of the Friendly Societies, or (and which would be the most effective means of accomplishing the object in view) by such an amendment of the Friendly Societies' Act as would limit sickness insurance to 65 years of age." The Odd Fellows' Magazine, August 1892, p. 250. 
societies, ruled out any concerted approach to the vexed question of impending or actual insolvency. Nothing in short had been done down to the closing years of the nineteenth century to remove a major cause of financial weakness. ${ }^{1}$ It was partly as a reaction to this failure of the voluntary agencies to put their own houses into order that groups of individual members began to work within, and outside, the friendly societies' movement for some form of state pensions.

This fresh challenge to deeply cherished beliefs was to achieve a modest degree of success during the latter part of the 1890s. In 1895, for instance, a delegate conference of friendly societies in the Birmingham area adopted a resolution "affirming the desirability of enacting a comprehensive system of old-age pensions". ${ }^{2}$ In the following year the annual meetings of the Manchester Unity of Odd Fellows and the Hearts of Oak Benefit Society accepted the need for some form of state grant to alleviate the misery so often associated with advancing years. Both of these bodies expected the initiative in formulating a pensions plan to come from the government, although neither of them hesitated to give advice to the legislature as to the type of scheme which would most readily command their support. ${ }^{3}$ In 1896 and again in 1899 the Grand United Order of Odd Fellows, at that point in time in serious financial straits, came out in favour of a non-contributory state pension of $5 /$ - per week, "payable at the age of sixty". 4

Friendly society supporters of state pensions were not content, however, to operate exclusively within the framework of their individual orders. The more far-sighted among them realised that substantial progress might be recorded if they could co-ordinate their activities at a national level. It was principally to fulfil this aim that the Old-Age State Pension League was founded by Claverhouse Graham during the closing months of 1898. From its inception the League made no attempt to disguise the fact that it was catering solely for members of thrift agencies. Its programme of reform was based on the explicit repudiation of the concept of a universal, non-contributory state pension. In

1 Foresters' Miscellany, May 1894, p. 41, and February 1898, p. 296.

2 The Times, 14 May 1895.

s Foresters' Miscellany, July 1896, p. 94; The Odd Fellows' Magazine, July 1896, p. 218.

1 This quotation is taken from the 1899 resolution, which argued that state pensions were "a necessary corollary" to the Workmen's Compensation Act. The Times, 24 May 1899. The 1896 motion asked for 5/- per week pensions for "all members of friendly societies on reaching the age of 60". B. B. Gilbert, loc. cit., p. 561. 
essence it committed the League's supporters to agitate for a weekly pension of $5 /-$, payable at sixty-five, to all those who had been members of a friendly or benevolent society for at least twenty years. ${ }^{1}$ In spite, however, of the limited nature of its objectives, the very emergence of such a body was sufficient cause for alarm among more traditionally-minded officials. That alarm was reinforced when they examined some of the means which the League used to propagate its ideas. In their eyes its worst offence was that it had violated what they regarded as the non-political attitudes of the friendly societies' movement by its active intervention in the 1899 by-election at Exeter. On that occasion the League had not hesitated to canvass rival politicians for their views on the pensions issue and to advise the friendly society electors in the constituency to cast their votes according to the nature of the replies received. ${ }^{2}$

By 1900, therefore, this pro-pensions lobby had started to make some impact upon the friendly societies' world. At the same time, however, it is important not to overstress or overestimate its early achievements. Its successes have to be balanced against its failures; for its failures were real enough. Firstly, up to and including 1899 the state pensions question had only once been effectively debated at the National Conference of Friendly Societies, although this assembly alone could be regarded as expressing something akin to the collective conscience of the friendly societies' movement. Unless or until the National Conference endorsed the principle of non-contributory pensions, the Old Age State Pensions League could not claim to be anything more than an unrepresentative pressure group. Secondly, as pensions advocates were to learn from bitter experience, a vote in favour of state pensions at one annual meeting of a friendly society did not necessarily imply an irrevocable commitment to the cause. Such a decision was as likely to be reversed as reaffirmed by future conferences. This is exactly

1 The Odd Fellows' Magazine, November 1898, pp. 352-3; March 1899, p. 71; The Times 6 February 1899; Foresters' Miscellany, July, 1899 p. 471. Claverhouse Graham attacked the idea of universal pensions in no uncertain terms. "Neither from a financial, nor even from a moral standpoint, could he agree that the thrifty and thriftless alike ... should be provided and cared for, upon the same terms, in the same manner, and all at the cost of the nation alike. [Applause]. He was bound to say that in his judgment such would be a most immoral transaction. Therefore, he was not an advocate of universal pensions." The Odd Fellows' Magazine, July 1899, p. 275. Claverhouse Graham was Grand Master of the Manchester Unity of Odd Fellows in 1893-4.

2 Foresters' Miscellany, December 1899, pp. 628-9. There was, however, little substance in the assertion of the "traditionalist" lobby that the friendly societies in any meaningful sense stood aloof from politics. The major societies had Parliamentary Agents whose duty it was to safeguard their interests. 
what was to occur in the case of both the Foresters and the Manchester Unity of Odd Fellows.

At their 1892 High Court meeting the Foresters had passed a resolution accepting the principle of old-age pensions, although only in the most general terms. ${ }^{1}$ Thereafter, for the remainder of the $1890 \mathrm{~s}$, they refused to have anything further to do with the notion. At the 1895 annual conference of the Order a resolution calling for "a pension for every working man on arriving at the age of 65 years" was withdrawn from the agenda by the High Chief Ranger without any debate taking place. $^{2}$ In the following year the High Court decided, by an overwhelming majority, that state-aided pensions "would be detrimental to the best interests of the Friendly Societies."3 In 1897 the pro-pensions delegates again suffered defeat, while in 1898 a less ambitious project - an attempt to secure a referendum on the subject - met with a similar rebuff. ${ }^{4}$

The Manchester Unity's debates on the same issue followed an almost identical course. After the 1891 Annual Movable Committee had unanimously adopted a resolution which described state pensions as inimical to "the best interests of the friendly societies of the country", the topic was not discused again until the 1895 gathering. Then the assembled delegates rejected by a two-to-one majority a motion calling on the state "to afford provision to destitute persons, whose destitution is occasioned by incapacity for work, resulting from old age." 0 The following year Claverhouse Graham and his followers secured their solitary triumph of the decade when the conference pledged itself to support "any well-considered and suitable [government] scheme ... for the relief of the aged and infirm benefiting our unfortunate brethren ... provided that the pension is independent of the Poor Law, and does

1 Ibid., September 1892, p. 194.

2 Ibid., June 1895, p. 67, and October 1895, p. 188.

'Ibid., September 1896, pp. 179-80. The voting was 224 for, and 90 against, this amendment to a pro-pensions resolution.

Ibid., September 1897, pp. 147, 167-69, and September 1898, pp. 178, 181. There also took place in 1898 a debate on state pensions. An amendment was carried by 305 votes to 17 asserting that since the Order already possessed a pensions scheme, any question of pensions for non-members "must be relegated to others whose duty it is to secure the well-being of the community at large." Ibid., October 1898, pp. 187-90. As the subsequent history of the Foresters revealed, this was not to be interpreted as an attempt to prod the government into immediate action. It was more likely a manoeuvre designed to remove the pensions issue from the arena of debate. To some extent it achieved a short-term triumph, for all pro-pensions resolutions were withdrawn at the $1899 \mathrm{High}$ Court Meeting. Ibid., September 1899, p. 554.

'The Odd Fellows' Magazine, July 1891, p. 219.

Ibid, July 1895, p. 230. The voting was 158 for, and 320 against, this proposition. 
not create any power of Government interference in the general management of the affairs of the Unity."1 In 1897 the question was not debated, while in 1898 a resolution, asking that the society's officers, "when acting in an official capacity will not do anything of a nature contrary to the spirit" of the 1896 motion, was rejected. ${ }^{2}$ It was clear from the tenor of the speeches that the 1898 vote was interpreted as reversing the pro-pension decision taken two years earlier. The last Annual Movable Committee of the nineteenth century implicitly accepted this verdict by ignoring completely the state pensions issue. ${ }^{3}$

Thus at the dawn of the new century there was little evidence to suggest that friendly societies, meeting in conclave at their National Conference, were about to commit themselves to the idea of a state pensions scheme. Everything seemed to point to a protracted internal wrangle over the advantages and drawbacks of state aid to the elderly; nothing pointed to a rapid triumph for the Old Age State Pension League. Certainly the COS, the most extreme critic of state intervention in the closing years of the Victorian era, must have analysed the situation in roughly these terms. The COS's leading anti-pensions spokesmen, Charles Loch and Sir William Chance, might have viewed with some apprehension the slowly growing strength of the pensions lobby among the friendly societies' rank and file, but they were able to console themselves with the thought that the ultimate outcome of the conflict was far from decided. In their scheme of things the major voluntary agencies were still to form the institutional framework within which self-help was to be practised; and it was inconceivable that at this late hour friendly societies would wish to abdicate this task which they had so honourably and for so long discharged. It was perhaps partly with a view to reinforcing those friendly society voices which were raised in defence of voluntaryism that the COS in 1899 intensified its own campaign against state pensions. Shortly after the Old Age State Pension League had been formed, the COS decided to set up a special pensions committee. ${ }^{4}$ Although this committee was to function independently of the parent body, it was nonetheless expected to play the rôle of a dutiful son. It was to be entrusted with the duty of prop-

1 Ibid., July 1896 , p. 218 . The voting was 290 for, and 244 against the motion. Eleven representatives abstained, while a further 66 were absent when the vote was taken.

2 Ibid., July 1898, pp. 229-30. The voting was 241 for, and 301 against, the motion. Ibid., June 1899.

4 The Times, 20 March 1899. This committee did include individual members of friendly societies such as George Abbott, editor of Foresters' Miscellany, but it did not meet with the formal approval of the Affiliated Orders. For its membership and its literature, see Old Age Pensions, A Collection of Short Papers (London, 1903). 
agating those "views with which most members of the Society were in sympathy". 'Tactically this committee's best hope of making an impact upon the apathetic lay in trying to establish a broad measure of agreement between itself and sympathetically inclined thrift agencies. Long before, however, it had begun to operate effectively, the COS had driven a wedge between itself and the friendly societies' movement.

This clash had its origins in a resolution, adopted by the 1899 National Conference of Friendly Societies, pressing for a revision of the 1894 Outdoor Relief (Friendly Societies) Act. ${ }^{2}$ Under the terms of this measure it had been left to the discretion of Boards of Guardians, entrusted with the duty of administering the Poor Law, as to whether or not friendly society benefits should be taken into account when awarding outdoor relief. The inherent defect of this type of legislation was obvious enough. Friendly society members received favourable or unfavourable treatment from the Poor Law not necessarily according to real need but rather according to the use which local guardians made of these discretionary powers. ${ }^{3}$ As the National Conference saw it, this anomaly could only be removed if there were fresh legislation on the subject. Hence its sponsorship in 1899-1900 of a new Outdoor Relief (Friendly Societies) Bill, the sole aim of which was to scrap all discretionary powers and to replace them with a set of unequivocal directives which would be binding on all Boards of Guardians. It was now proposed that an individual should be allowed to receive up to 5/- per week from friendly society sources and that Poor Law officials should ignore this income when relieving his needs. ${ }^{4}$ To most friendly societies such a change in the law would be in conformity with the principles of equity. To the COS, however, the proposal was "tantamount to a partial repeal of the Poor Law Act of Queen Elizabeth". 5 Loch himself objected to the bill on two counts. Firstly it represented "a sectional demand for a bonus out of public funds for friendly societies' men". By thus helping to create a class of preferential

1 31st. Annual Report of the Council of the C.O.S. (2nd edition ,1900), p. 16. 2 Foresters' Miscellany, June 1899, p. 441. It is interesting to note that the National Conference of Friendly Societies gave its support to the 1894 measure. See on this point The Odd Fellows' Magazine, May 1894, p. 142.

- The Odd Fellows' Magazine, January 1904, p. 8. Claverhouse Graham, the Parliamentary Agent of the Manchester Unity of Odd Fellows, argued that the 1894 Act was favourably interpreted "by the great majority of Boards of Guardians". It was only necessary to seek to amend the 1894 measure because of the minority of Boards of Guardians who refused to carry out the permissive clauses of the Act.

- Foresters' Miscellany, March 1900, p. 71.

s The Times, 24 June 1901.

- Ibid., 16 March 1903. 
paupers, the bill would lead to an expansion in the scope of the Poor Law. In itself this was a totally undesirable development. But secondly, even if it could be argued that the proposal would not undermine thrift - and Loch did not believe this for one moment -, it would produce as many inequities as it was designed to solve. In Loch's words, "it confers on members of friendly societies the privilege of additional Poor Law relief, while it withholds this privilege, if privilege it be, from other equally thrifty and careful men." 1 Yet by committing the COS to oppose this bill, Loch did much to destroy the rapport which had hitherto existed between his own organisation and the friendly societies' movement. On each occasion the bill came before Parliament bitter feelings were engendered on both sides of the fence. It was symptomatic of this speedy deterioration in relations that $\mathrm{J}$. Lister Stead, Permanent Secretary of the Foresters, could attribute the measure's rejection by the House of Lords in 1903 "chiefly ... to the persistent and extraordinary opposition of the Charity Organisation Society". ${ }^{2}$ When, therefore, the bill finally reached the statute book in August, 1904, friendly society members felt that they had triumphed in spite of Loch and his colleagues.

On this particular issue the COS might have congratulated itself for putting principle before all considerations of expediency. But had it been less blinded by its own doctrines, it would have realised the importance of reaching a modus vivendi with the major friendly societies on a question which was far removed from the pensions controversy. For at roughly the same time as the COS-National Conference of Friendly Societies' quarrel over the Outdoor Relief Bill was taking place, the pro-pensions forces outside the ranks of the voluntary agencies were advancing on all fronts. In 1899 the National Committee of Organised Labour for Promoting Old Age Pensions for All was founded and from the outset received substantial support for its programme of a universal non-contributory pension from leading trade unionists. Some hint of its determination to achieve its goal was given when, within weeks of its formation, it actively intervened in the 1900

1 Ibid., 24 June 1901.

2 Foresters' Miscellany, May 1904, p. 129. Perhaps even more revealing was the comment of E. F. Hind, Grand Master of the Manchester Unity, when the bill finally reached the statute book. Speaking at the 1905 Annual Movable Committee of his Order, he asserted that the measure had been made law, "notwithstanding the opposition of the Charity Organisation Society, which must have spent a considerable sum of money in their attempt to defeat the wishes of the friendly societies in this matter." This speech was reported in The Odd Fellows' Magazine, July 1905, p. 244. 
General Election. ${ }^{1}$ Another indication of the changing climate of opinion was the acceptance by the Council of the Association of Poor Law Unions of a pro-pensions report from one of its sub-committees. ${ }^{2}$ But perhaps of greater significance than these developments, there were unmistakable signs that some politicians were coming to realise that the state had a moral obligation to alleviate cases of hardship amongst the aged. Tangible proof of this concern was given in 1900 when the Local Government Board Circular on Relief to the Aged Poor was issued. This document, in recommending that all deserving applicants should be given adequate outdoor relief, was a tacit acknowledgment that "old-age pauperism" might be as much the product of personal misfortune and/or low wages as of a failure to follow the Smilesian precepts. On the pensions issue itself political thinking was also undergoing a slow but perceptible metamorphosis. In 1899 a Select Committee of the House of Commons, headed by Chaplin, had reported in favour of a non-contributory payment of 5/- weekly to deserving cases. Such benefits were to be under the control of local Boards of Guardians and were to be jointly financed by the local poor rate and the Exchequer. Thus whereas the Aberdare and Rothschild inquiries had frowned on the idea of state pensions, a committee composed exclusively of M.P.s had given it a heavily qualified benediction. ${ }^{3}$

It was true that the outbreak of the Boer War removed, in the shortterm, any possibility of government action on the pensions question even if the will to act had been present. It did not however follow that politicians then proceeded to forget all about the plight of the elderly. This much was made clear when the dominant figure in the Conservative ministry, Joseph Chamberlain, returned to the pensions theme in 1901. Once more addressing his remarks to the friendly societies, he asked them to draft a pensions plan and to present it to the government for action. No administration, he argued, would refuse to implement pensions proposals which had secured the prior approbation of the friendly societies' movement. 4

Faced by such formidable forces, the opponents of state pensions could only hope to mount an effective counter-offensive if they could

1 1st. Annual Report of the National Committee of Organised Labour for Promoting Old Age Pensions for All, 1899-1900 [n.d.], p. 6; 2nd. Annual Report of the National Committee ... July, 1900-July 1901, pp. 9-12.

${ }^{2}$ Charity Organisation Review, July 1899 , pp. 3-4.

3 The Aberdare Commission on Old Age Pensions which sat from 1893 to 1895 , came out in favour, in its majority report, of a policy of leaving the pensions question to the friendly societies. The Rothschild Committee (1896-98) was only permitted to examine contributory pensions proposals. It was unable to recommend to the government any of the four schemes it scrutinised.

'The Foresters' Miscellany, July 1901, pp. 520-4; September 1901, pp. 584-5. 
agree among themselves. The COS's attack, however, on the Outdoor Relief (Friendly Societies) Bill had virtually ruled out the prospect of co-operation between itself and the two large Affiliated Orders. Outside observers were thus confronted with the spectacle of disharmony among the ranks of the anti-pensions advocates at a time when the threat to their position had never been more ominous.

The reality of this threat was underlined by the growing interest which the National Conference of Friendly Societies was taking in the state pensions issue. At the 1900 conference there had been a debate on a motion, moved by the Grand United Order of Odd Fellows, demanding an old-age pension of five shillings per week for all members of friendly societies who had reached the age of sixty-five. ${ }^{1}$ The following year a resolution, couched in almost identical language, produced a lively discussion. ${ }^{2}$ Although on neither occasion were these pro-pensions motions carried, ${ }^{3}$ they nevertheless marked an important new phase in the pensions debate. They heralded nothing less than the beginning of the struggle between conflicting factions for the collective conscience of the friendly societies' world. Both sides believed - and not without reason - that the Government's willingness or reluctance to intervene in the pensions field would hinge to some extent on the outcome of that struggle. Accepting therefore the repercussions which any decision of the National Conference of Friendly Societies, favourable to state pensions, might have in political circles, and anticipating a renewal of the debate at the 1902 meeting, the Executive Committee of the Foresters tried to rally the voluntaryist forces by issuing a forceful address covering all aspects of the pensions question.

Published in February 1902, this manifesto was ostensibly produced for the edification of the Order's own membership. In a wider sense, however, its message was aimed at all those thrift agencies which entertained views similar to those of the Foresters on the undesirability of state interference in the area of social welfare. The document began by attributing the revival of interest in old-age pensions to Chamberlain's 1901 speech. Yet, it asserted, "the present time hardly seems favourable for promoting schemes of a costly character, such as an effective plan of Old Age Pensions would be, in view of the heavy taxation borne, and to be borne, by this country as a result of the South African war, even if we were convinced that State action upon the lines thrown out by Mr. Chamberlain were advisable or necessary."

1 The Odd Fellows' Magazine, April 1900, p. 113.

2 The Foresters' Miscellany, April 1901, pp. 452-3; The Odd Fellows' Magazine, April 1901, p. 105.

3 In 1900 the previous question was moved and carried. In 1901 the resolution was withdrawn at the end of the debate. 
This sentence set the tone for the rest of the address; for the Executive Council again tried to show that state pensions would be a socially disastrous step for any government to take. Leaning heavily on Smilesian teaching, it looked "to the continuance of the operation of selfhelp and independence as a means of social regeneration of the people". All men and women should be encouraged "to strive to improve their own position rather than depend upon doles from the State". There were, it conceded, people who failed "in life through circumstances not always controllable by them". For this section of the population - the aged deserving poor - the Poor Law should be "so amended that the relief given to them may be as free from reproach as through any other channel." The undeserving aged poor should continue to be dealt with under the existing system of Poor Law administration. The principal rôle however in helping the working-classes to provide for their old age was still to be reserved for the friendly societies. Security for the working-man could be guaranteed if "they [the friendly societies] will insist upon all new members paying for a pension, either with or without sick pay, in old age; also [if they] give facilities for existing members to exchange their present benefits for benefits to include a pension." There was thus scant justification for any form of state pension, although it appeared that the topic was to be raised again at the forthcoming National Conference of Friendly Societies. Appropriately therefore the manifesto concluded with a discussion of the strategy which the Forester's delegates should employ when the inevitable pro-pensions resolution was proposed. Initially they should attempt to persuade the Conference to accept an amendment condemning "state-aided pensions" as being "detrimental to the best interests of Friendly Societies". Should that ploy fail, they should insist that no pension scheme should be adopted in the name of the National Conference until two things had been done. Firstly, it should be submitted to delegate meetings of all affiliated societies. Secondly, it would have to secure the formal approval of a specially convened National Conference devoted exclusively to the pensions issue. ${ }^{1}$

In spite of all their elaborate precautions, however, the Foresters' Executive - and indeed the whole of the anti-pensions movement were to suffer a crushing reverse at the 1902 National Conference when the assembled delegates voted by a substantial majority in favour of a state pension "of not less than 5s. a week for all thrifty and deserving persons of 65 years of age and upwards who are unable to work and in

1 This paragraph has been entirely based on the Executive Council of the Foresters' Address on Old Age Pensions, The Foresters' Miscellany, February 1902 , p. 40. 
need of the same". ${ }^{1}$ Only two qualifications were to be made to this broad statement of principle. In the first place the receipt of a pension was not to involve "any disability of citizenship". Secondly, the means of raising revenue for the scheme should not entail "any interference with the funds of thrift societies". ${ }^{2}$ But as all ardent supporters of state pensions by now realised, it was not sufficient to secure the adoption of such a motion, and then to leave things alone. If their cause were to make any further progress, it was essential to ensure that this resolution was translated into a carefully thought-out programme of social reform. Hence one of the last acts of the Conference was to devolve this duty on the shoulders of a newly appointed sub-committee. Once the subcommittee had formulated its proposals, they were to be presented, as the Foresters had suggested, to an extraordinary general meeting of the National Conference. That gathering would in its turn have to decide whether or not it wished to sponsor the plan which its representatives had prepared for its consideration. ${ }^{3}$

\section{VI}

The sub-committee's scheme, when it was finally made public, ${ }^{4}$ clearly disappointed the more sanguine advocates of state pensions. Many propensions supporters had hoped that the sub-committee might advance cautiously towards Booth's concept of universality. Instead they discovered that it had interpreted its brief in a remarkably narrow sense. Its main preoccupation had been with evolving a series of tests designed to measure desert, thrift and need. Following very closely in the steps of the COS, it began by identifying desert with character. Thus, the first requirement that a would-be pensioner had to fulfil was that he (or she) "has not habitually received Poor Law relief, has not been convicted of a felony within 25 years of age 65 , has not been convicted of any offence of less gravity than felony within ten years of age 65, and is not leading an immoral life." Having surmounted this hurdle, the claimant had then to provide proof that he (or she) had "endeavoured to the best of his or her means, to be provident." Acceptable evidence of thrift ranged from membership of a friendly society or a trade union providing welfare benefits to deposits in a building society, membership of a co-operative society or home owner-

1 The Foresters' Miscellany, February 1903, p. 29. For the debate itself see The Foresters' Miscellany, April 1902, pp. 85-7, and The Odd Fellows' Magazine, April 1902, pp. 107-8.

2 The Foresters' Miscellany, February 1903, p. 29.

3 Ibid., April 1902, p. 87.

- Ibid., February 1903, p. 29. It was published on New Year's Day 1903. 
ship. Last of all the sub-committee sought to measure need in terms of weekly income. Where the income of a married couple exceeded 15/per week and that of a single person rose above $10 /-$ per week, all rights to a state pension were to be forfeited. ${ }^{1}$

Friendly societies were in effect being asked to accept a plan which enshrined most of those values they held most dear. But it was precisely because this scheme was so inward-looking that it lacked an overall sense of balance. It attempted for instance to draw a distinction between the deserving and undeserving poor which completely lacked conviction. Booth's and Rowntree's statistical work had been ignored - could a dock labourer with a large family ever afford to belong to any type of thrift agency? - in favour of the COS's thesis that the practice of self-help was mainly associated with good character.

Such points, however, tended to be overlooked amidst the torrent of discussion which followed in the wake of the sub-committee's recommendations. Hind, for example, a prominent member of the Manchester Unity, denounced the whole conceptual framework of the plan. It was a compromise which "suited nobody - neither the State Pensioners nor the Anti-State Pensioners. He did not know that a more objectionable scheme could have been proposed by anybody who had given any consideration to the question." 2 Equally vigorous criticism of the proposal came from the more conservative George Abbott, editor of the Foresters' Miscellany, who charged the sub-committee with trying to undermine the prosperity of the working-classes. The plan, as it stood, would lead to pensioners accepting work at a rate of pay below that currently obtaining in the labour market. "In these cases", Abbott concluded, "the only person who gets any real benefit from the pension is the sweating employer, who takes advantage of the pension to pay less wages than he otherwise would do, and to increase his profit thereby." 3 But the discussion of the issues involved was not, and indeed could not be, restricted to the friendly societies' world. Outside bodies with a keen interest in welfare questions were equally anxious to pronounce on the sub-committee's work. The COS, for example,

1 Ibid., p. 36. It is interesting to note that "any sum not exceeding 5s. per week from registered Friendly Societies or registered trade unions" was not to be counted as income. The sub-committee was thus early anxious to see this principle, embodied in a permissive form in the 1894 Outdoor Relief (Friendly Societies) Act, extended to the sphere of state pensions. The National Conference was to succeed in 1904 in persuading Parliaments to compel Boards of Guardians to exclude the first five shillings of an applicant's income from friendly society sources when awarding him outdoor relief. This change formed the cornerstone of the 1904 Outdoor Relief (Friendly Societies) Act.

2 The Odd Fellows' Magazine, July 1903, p. 352.

'The Foresters' Miscellany, February 1903, p. 31. 
deriving scant comfort from the fact that this proposal was designed to cater for the "deserving poor", remained bitterly hostile to the idea of non-contributory pensions. The friendly societies, it felt, would be doing Booth's work for him if they endorsed this plan, since there were no safeguards to prevent the scheme from "at once degenerating into a universal allowance". Furthermore, "the feebleness of the executive [i.e. the Pensions Authority] would provoke wholesale fraud on the part of the recipients." 1 The National Committee of Organised Labour for Promoting Old Age Pensions for All on the other hand believed that the sub-committee had provided additional proof that any pensions proposal "short of universal pensions is indefensible as a matter of justice and impracticable in administration." Yet notwithstanding this glaring defect, it was still prepared to give a qualified approval to the plan. ${ }^{2}$ However, early reactions such as these did not neccessarily indicate what form the final judgment of the National Conference of Friendly Societies would take at its special assembly, summoned to meet at Brighton in October 1903.

\section{VII}

The Brighton Conference gave the anti-pensions forces their last real opportunity of reversing the decision which had been taken in March 1902, although the pattern of events since that date suggested that their hopes of success could not now be high. The Foresters' leaders in particular had been badly shaken by developments within their own Order during the intervening eighteen months. Their Executive, for instance, had been humbled at the 1902 High Court meeting when an anti-state pensions resolution had been rejected in favour of an amendment calling for a referendum among the Foresters' membership on the pensions question. ${ }^{3}$ The resultant ballot had shown that while the rank and file rejected the schemes linked with the names of Blackley, Booth, Chamberlain and Chaplin, they accepted, by a more than two to one majority, the resolution of the 1902 National Conference as the basis for a settlement of the pensions issue. By a much narrower margin they also decided that state pensions would not exercise a harmful influence on the friendly societies' movement. ${ }^{4}$ Although it was true that the Foresters' Executive recovered some of this lost ground at the 1903

1 Charity Organisation Review, January 1903, pp. 3-4.

2 The Times, 9 February 1903.

3 Foresters' Miscellany, September 1902, p. 266, and October 1902, pp. 284-5. The amendment was carried by 298 votes to 245 .

4 Ibid., August 1903, pp. 224-6. Only 14\% of the Order's United Kingdom membership participated in this referendum. 
High Court when the Order's delegation to the forthcoming Brighton Conference was instructed "to vote against the [sub-committee's] scheme as at present submitted", 1 the results of the referendum itself could not fail to be a source of encouragement to all supporters of the state pensions' cause. The Manchester Unity of Odd Fellows was likewise at this period beset by internal difficulties, although they differed markedly in character from those with which the Foresters' leadership had recently been grappling. Outwardly the Manchester Unity remained implacably opposed to state pensions; down to 1902 there had not even been an attempt to reverse the anti-pensions vote taken at the 1898 Annual Movable Committee at any subsequent conference. But this had not prevented two of the society's delegates to the 1902 National Conference of Friendly Societies from voting in favour of a state pensions resolution. ${ }^{2}$ This open split must have suggested to outsiders that the Manchester Unity did not really know its own mind on the subject. Instead, however, of guarding against a repetition of this behaviour, the 1903 Annual Movable Committee agreed to give its delegation a free hand at the Brighton Conference. Matters were made worse when at least four of the ten men who were selected to attend, were known advocates of noncontributory pensions. It therefore seemed likely that the Manchester Unity would again on this issue give the appearance of being a house divided against itself. ${ }^{3}$

This was precisely what happened. Almost as soon as the Brighton meeting had begun, the Unity's representatives found themselves speaking and voting on opposite sides of the pensions fence. Such a public display of disharmony could not but have a far-reaching effect on the ultimate outcome of the debate. In effect it meant that the Foresters' leaders, deprived of the wholehearted support of their staunchest allies, were faced with the daunting task of trying to persuade the Conference to steer clear of any contact with the idea of non-contributory pensions. Not surprisingly they failed. At the end

1 Ibid., October 1903, pp. 295-6.

2 Ibid., July 1902, pp. 182-3.

- The Odd Fellows' Magazine, July 1903, pp. 352-3. The sub-committee's scheme was treated with equal nonchalance. The following motion was passed: "That until a scheme has been drafted which in the opinion of the A.M.C. can be submitted to the members it is not necessary to take steps to ascertain their opinions." A leading article in the October 1903 issue of the magazine interpreted this motion as committing the Manchester Unity to vote against the pensions scheme at Brighton. It clearly involved no such thing. Ibid., October 1903, pp. 452-3. 
of the day the National Conference had adopted in its own name a revised version of the sub-committee's scheme. ${ }^{1}$

This verdict was never to be seriously challenged at any future National Conference. Partly, it is true, this was because the years 1903-6 were largely given over at a national level to a debate about the advantages or disadvantages which might accrue to Great Britain if she abandoned her longstanding commitment to free trade. In a word, Chamberlain's forceful campaign for imperial preference tended to push social reform into the background and hence to reduce to some extent the need to take up cudgels against the 1903 pensions scheme. Every element in the state pensions movement was thus forced to mark time while Liberal and Conservative politicians vied with one another in discussing the merits or demerits of returning to a limited form of protection. The 1903-4 Report of the National Committee of Organised Labour for Promoting Old Age Pensions for All summed up the pro-pensions lobby's feelings when it lamented these developments which had so effectively blocked the path of "constructive reform". ${ }^{2}$ The following year it was again compelled to admit that it had held

1 For a detailed account of the Conference, see Foresters' Miscellany, November 1903, pp. 329-332. Two essentially wrecking amendments moved by the Foresters were lost by the crushing margins of 40 votes to 11 and 40 votes to 12 . This report of the Brighton deliberations observed that "there were members of the Conference who did not take kindly to the amendments moved by representatives of the A.O.F., and by their votes defeated same by large majorities, but when the detailed discussion came on, the attitude of the representatives of the A.O.F. was fully justified and upheld." For the internal divisions among the Odd Fellows' delegation see The Odd Fellows' Magazine, November 1903, pp. 496-98. That same source - p. 498 - recorded the fact that the thrift tests suggested by the sub-committee were replaced by a general clause. In effect this laid down that an applicant who had, "according to the judgment of the pensions authority, endeavoured, to the best of his or her means or opportunities, to be provident" should qualify for a state pension. A further alteration was to be made to the scheme at the 1904 National Conference. See Foresters' Miscellany, May 1904, p. 134.

2 5th. Annual Report of the National Committee for Promoting Old Age Pensions for All, July 1903-July 1904, p. 7. "The fifth year [of our campaign] has been full of political excitement, which has not been helpful to us. "The National Committee's finances were at this juncture at such a low ebb that Frederick Rogers, its Organising Secretary, agreed to go for 12 months without a salary. He was clearly being paid and employed during this period of time by Messrs Rowntree and Sherwell in connection with their scheme of 'Constructive Temperance Reform'. The Report concluded thus: "the work has been longer than we thought at first, but we have had loyal supporters and faithful friends, and if we all resolve to keep it steadily in the forefront of politics, it is the one piece of constructive legislation before the country today, and we shall yet see the reward for our labours". Ibid., pp. 11-12. 
fewer meetings than hitherto, although it decided that "this has not meant that there has been less enthusiasm but rather that - as regards Old Age Pensions - the public mind is made up."1 Such optimism would have been shared by few state pensions supporters within the friendly societies' world.

Another factor which can in part account for the seeming reluctance of the anti-pensions forces to try to reverse the Brighton verdict was the secession in 1904 of the Manchester Unity of Odd Fellows from the National Conference's deliberations. Without some guarantee of powerful outside support such as the Manchester Unity might have provided, the Foresters were understandably enough unwilling to challenge by themselves the 1903 commitment to non-contributory pensions. ${ }^{2}$ Nonetheless this point should not be overstressed for two reasons. Firstly, as has been demonstrated, successive delegations of the Odd Fellows to the 1902 and 1903 National Conferences had scarcely distinguished themselves as unswerving defenders of the voluntaryist cause. Rather than vote as a bloc against state pensions, they had tended to fall out amongst themselves whenever the issue had been raised. In the second place the Manchester Unity and the Foresters had by the middle of 1908 turned their backs on their past history by

16 th. Annual Report of the National Committee for Promoting Old Age Pensions for All, July 1904-July 1905, p. 7. It was recorded that Rogers, after working for a year on "Constructive Temperance Reform", had returned as full-time secretary.

2 The Manchester Unity had broken with the National Conference of Friendly Societies over the question of the existing system of delegate representation. It felt that the system as it stood discriminated against the numerically powerful orders by giving to the smaller societies an influence out of all proportion to their membership figures. Only after the Manchester Unity had failed to persuade the 1904 National Conference to end this situation, did it take the decision to disaffiliate. See The Odd Fellows' Magazine, June 1904, pp. 310-3, and January 1905, p. 7. Individual members of the Hearts of Oak tried to argue that the rootcause of this defection was the victory of the pro-pensions forces at Brighton, see Hearts of Oak Gazette, 1 August 1904, and Hearts of Oak Journal, July 1907, p. 38. What, however, such assertions overlooked was that the question of withdrawing from the National Conference had first been debated before the Brighton Conference had ever met and that on that occasion - the 1903 Annual Movable Committee of the Manchester Unity, - the main grounds for recommending such a course of action had been the under-representation of the larger societies. Furthermore, when the decision to withdraw was finally taken, one of the most vehement supporters of the proposition was Claverhouse Graham, the founder of the Old Age State Pensions League. The Odd Fellows' Magazine, July 1903, pp. 311-5, and June 1904, p. 310. In the end only "about twenty hands" were raised against disaffiliation. Ibid., June 1904, pp. 312-3. The Manchester Unity voted to reaffiliate to the National Conference at its 1908 annual meeting. See Ibid., July 1908, p. 354. The voting was 284 for, and 237 against, reaffiliation. 
accepting the case for state pensions. The declining strength of the anti-pensions forces during 1907 and 1908 was, in other words, to be reflected in a sudden shift of opinion within these two Affiliated Orders in favour of Exchequer-financed benefits for the elderly.

Little hint, however, of this impending change of heart was given by either the Manchester Unity or the Foresters during 1904-6, when the question of state pensions was never raised at any of their annual meetings. Even when the Manchester Unity did at last return to the theme at their 1907 Annual Movable Conference, an innocuous propensions resolution was thrown out almost without debate. ${ }^{1}$

But before then - July 1907 - the Foresters had already abandoned their previous stand. As soon as the government had announced that it hoped to tackle the pensions problem in the near future, the change in the Foresters' attitudes became strikingly apparent. J. Lister Stead, who had been a tireless worker in the late 1890s in the campaign against state pensions, was one of the first to confess the error of his previous ways. In so doing he was to repudiate virtually every argument that the Foresters had ever used against state provision for the aged members of the community. "The Government," he acknowledged, "have done well to recognise the widespread objection to any association of State pensions with the Poor Law", thus overlooking the fact that his own order had long desired to see the problem of the aged deserving poor solved within the framework of a "humanised" Poor Law. He accepted, too, "the views enunciated on behalf of the Government in the direction of practically universal pensions" and promised "that in proceeding upon this line the Government will have, if needed, the assistance of the greater part of the members of Friendly Societies." This again indicated that a fundamental shift in Stead's own thinking had taken place. Whereas he had formerly frowned upon friendly societies having any sort of formal relationship with the state, he was now suggesting that they should actively co-operate with the Liberal administration. Finally he explicitly rejected the 1903 subcommittee's scheme although he had helped to draft it. He had, he said, "come to recognise, with many others whose views have also changed, that any scheme with limitations, such as the fixing of an income standard or the proving of inability to work is calculated to be detrimental to thrift. The certainty of a State pension at a given age is, on the other hand, an encouragement to aid through individual effort to that which the State provides." 2

1 Ibid., July 1907, p. 397.

2 Foresters' Miscellany, April 1907, p. 606 (extracted from Yorkshire Daily Observer 8 March 1907). "Force of circumstances, if nothing else, brings agreement with the views enunciated on behalf of the Government in the direction 
Almost identical sentiments were expressed at the March 1907 National Conference of Friendly Societies. Although still at that juncture formally committed to their own sub-committee's plan, delegates were forced to acknowledge that "circumstances" had changed out of all recognition between 1904 when they had made the final modifications to their own proposal and the closing months of 1906 when Campbell-Bannerman and Asquith had paid lip-service to the principle of universal, non-contributory pensions. "The Conference scheme", it was decided, "was only intended as a step towards a larger one"; "the feeling [now] was in favour of what was contemplated by the Government as already outlined."' Before ever, therefore, the Liberals had worked out their pensions blueprint in any detail, opinion among the larger thrift agencies was drifting towards the concept of universality which had for so long been associated with the name of Charles Booth and the National Committee of Organised Labour for Promoting Old Age Pensions for All. Nothing made this clearer than the results, published early in 1908, of the Chief Registrar's inquiry into friendly society reaction to an Exchequer-financed pensions plan. Asked to comment on the question as to whether a non-contributory scheme would harm their interests, sixty-seven societies replied in the affirmative and sixty-four in the negative. Fears, however, of the effects of government intervention were principally expressed by the smaller thrift agencies, many of them operating on almost a parochial basis. Of those organisations with memberships in excess of 49,000 , three, representing between them slightly more than 420,000 individuals, expected non-contributory pensions to affect them adversely. As against this six societies, with over $1,400,000$ members, enthusiastically welcomed the idea of a non-contributory scheme, while a

of practically universal pensions." Ironically enough, Stead had been both a member of the 1902 National Conference pensions sub-committee and had presided over the 1903 Brighton Pensions Conference, although the Foresters were at that point in time opposed to state pensions. At Brighton, he had "appealed to the Conference to keep clear of partizanship, and suggested some resolution similar to that adopted by the Ancient Order of Shepherds, in these words - 'That the question of providing maintenance for the aged and deserving poor is one for the statesmen of the country to deal with', would meet the case, concluding with the hope that the various Societies would endeavour to improve and consolidate their own Societies." See Ibid., November 1903, p. 329 and April 1907, p. 605.

1 Ibid., April 1907, p. 615. These sentiments were expressed in a debate about whether or not the National Conference's representatives before the 1905-9 Royal Commission could support a universal, non-contributory scheme. At the 1906 National Conference, however, it had been resolved to stand behind the sub-committee's plan in the form it had been amended in 1904. See Ibid., May 1906, p. 129. 
further two, with 200,000 members, returned ambiguous answers. The Manchester Unity of Odd Fellows alone among the Affiliated Orders refused to have any dealings with the inquiry on the grounds that "inasmuch as this matter is likely to be a source of contention in the political arena, this board [of directors] declines to express an opinion thereon."1

Thus at the beginning of 1908 the Manchester Unity was not merely cut off from the National Conference of Friendly Societies; it was also the only major friendly society which had refused to comment on the government's declaration of intent. It was impossible, however, to maintain this intransigent position for long. Once Asquith had outlined in May 1908 the nature of the Liberals' scheme, the Unity had to decide, along with other voluntary organisations, how far this plan would help, and how far it would hinder, its own development. In the light of that analysis it had to formulate, and then to try to persuade the legislature to adopt, any appropriate amendments. Like the Foresters before them, the Odd Fellows had to learn how to adapt themselves to the changing climate of opinion both within and outside the friendly societies' world.

\section{VIII}

On the whole the reaction of the National Conference of Friendly Societies and its affiliated organisations was favourable to Asquith's 1908 plan despite the fact that for reasons of finance it fell a long way

1 These details are taken from Old Age Pensions (Non-Contributory Scheme) (Correspondence), [PP 177, 1908]. Those societies with more than 49,000 members who feared a non-contributory plan were the Lancashire and Cheshire Miners Permanent Relief Society (49,662 membership); the Northumberland and Durham Miners Relief Fund $(165,981)$; and the Independent Order of Rechabites, Salford Unity $(205,789)$. The supporters of the non-contributory principle included the Rational Association $(126,461)$; the Hearts of Oak $(289,342)$; the Foresters $(659,501)$; Grand United Order of Oddfellows (72,583); Loyal Order of Ancient Shepherds, Ashton Unity $(124,638)$; and the Order of the Sons of Temperance $(125,834)$. The National Deposit Friendly Society $(169,100)$ and the British Order of Ancient Free Gardeners $(52,794)$ refused to commit themselves one way or the other. The National Deposit Friendly Society argued that noncontributory pensions would have no adverse effect as "far as many Societies are concerned; but in Deposit Societies the effect might possibly be that the member would make less effort to save"; "would affect the thrift of the working classes though not to an appreciable extent. They might consider it less necessary to save". The British Order of Ancient Free Gardeners found it "difficult to determine [the impact of non-contributory pensions on the friendly societies' world]. Societies with deficiencies might find such a measure of immense value, as it would enable them to decide on Sick pay ceasing at a given age." Ibid., pp. 6-8, 10-11, 14-18, and 20. 
short of universality. The Committee of the National Conference spoke for the vast majority of its members when it welcomed "the beginning made by the Government in providing a more humane system of dealing with the aged people of this country". At the same time it entertained some reservations about the income limitations which were an integral part of the scheme. Fearing that such restrictions might, if left undisturbed, inhibit rather than stimulate thrift, the Committee asked that "in estimating the income of applicants for pensions, any amounts received from a Friendly Society or Trade Union, in the form of sick or pensions benefits, or voluntary grants in exceptional circumstances, may not be taken into account." 1 In an attempt to justify this request for preferential treatment - a request which was endorsed by the Annual Movable Committee of the Manchester Unity ${ }^{2}$ - the movement's leaders tried to demonstrate that savings made through friendly societies differed from all other forms of thrift. The most persuasive argument in favour of this thesis came from $T$. Barnes of the Odd Fellows, who maintained that "individual savings were not to be compared with the communal thrift inculcated by friendly societies. The mutual interests upon which their societies were based was a totally different thing to that which merely regarded a man's individual interests." ${ }^{3}$ Hence Parliament should yield to their legitimate demands.

Despite, however, the eloquence with which this change was urged on MPs by the Conservative opposition, ${ }^{4}$ neither Asquith nor Lloyd George was prepared to see the principles of the 1904 Outdoor Relief (Friendly Societies) Act extended to the sphere of old age pensions. As the government saw it, thrift agencies, in accepting the non-contributory principle - and this had been the National Conference of Friendly Societies' policy since 1902 -, had forfeited all real opportunity of influencing the exact shape state pensions should assume. The upshot paradoxically enough was that at the very time when many friendly societies were prepared to discard their own pensions plan in

1 Foresters' Miscellany, July 1908, p. 191. This resolution was adopted on 8 May 1908, the day after Asquith had made his proposals public in his Budget speech.

2 The Odd Fellows' Magazine, July 1908, p. 363.

3 Ibid., July 1908, p. 364.

4 Ibid., July 1908, pp. 438-9 and August 1908, p. 444. On 18 June 1908 LloydGeorge saw a deputation from the National Conference of Friendly Societies who urged him to embody this change in the government's pensions scheme. The non-committal reply of the Chancellor of Exchequer was equivalent to a rejection of this proposal. In the Commons on 30 June 1908 an amendment to exclude the first $£ 40$ per annum received from friendly society sources from the income assessment for pensions, was lost. For Conservative criticisms of the Pensions Bill, see The Times 16, 17 and 18 June 1908 and B. B. Gilbert, op. cit., pp. 222-3. 
favour of Booth's, the Liberals were opting for a scheme which bore a striking resemblance to the 1903 National Conference of Friendly Societies' proposals. ${ }^{1}$ In the end the idea of a universal pension was rejected and income and character tests were introduced. Nonetheless, in spite of all their shortcomings, non-contributory pensions were an explicit acknowledgment that the era of laissez-faire Liberalism was dead; that henceforth market forces were not to be the sole determinant of whether or not the elderly lived out their days without coming into contact with the Poor Law. In that sense at least 1908 marked an important turning-point in the welfare debate in early twentieth century Britain.

1 Foresters' Miscellany, August 1908, p. 213, claimed in a leading article that except for the age at which one was to be eligible for a state pension, the Liberals' proposals "carries out in a complete form" the 1902 National Conference of Friendly Societies' pro-pensions resolution. Under the government's plan pensions only began at 70 years of age. 